\title{
Starch synthesis and gelatinization properties of potato tubers
}

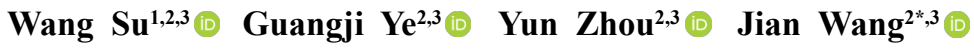 \\ ${ }^{1}$ Key Laboratory of Biology and Genetic Improvement of Tuber and Root Crop, Ministry of Agriculture and Rural Affairs, 100081, Beijing, China. \\ ${ }^{2}$ Academy of Agriculture and Forestry Sciences, Qinghai University / Qinghai Academy of Agriculture and Forestry Sciences, 810016, Xining, \\ Qinghai, China. E-mail: jianwang2197@163.com. "Corresponding author. \\ ${ }^{3}$ Engineering Research Center of Potato in Northwest Region, Ministry of Education, 810016, Xining, Qinghai, China.
}

ABSTRACT: Biosynthesis is the only source of potato starch which is an important raw material for food processing, modified starch and biomass energy. However, it is not clear about the evolution of starch synthesis with tuber development in potato. The present study evaluated the differences of starch synthesis and gelatinization properties of potato tubers with different starch content. Relative to cultivars of medium and low starch content, cultivars of high starch content showed significantly higher SBEII gene expression, AGPase and SSS enzyme activity, and total starch content after middle stage of starch accumulation, and had smaller average starch granule size during whole process of tuber development, and had higher pasting temperature before late stages of tuber growth, and had lower pasting temperature after middle stage of starch accumulation. Path analysis showed that, after middle stage of starch accumulation, effects on starch gelatinization of cultivars with high, medium and low starch content represented starch synthesis enzyme activity $>$ starch accumulation $>$ starch granule distribution $>$ starch synthesis enzyme gene expression, starch synthesis enzyme gene expression $>$ starch synthesis enzyme activity $>$ starch accumulation $>$ starch granule distribution, starch synthesis enzyme gene expression $>$ starch granule distribution $>$ starch synthesis enzyme activity $>$ starch accumulation, respectively. In the study, phases existed in the starch biosynthesis of potato tuber, and the starch quality and its formation process were different among varieties with different starch content. The findings might contribute to starch application and potato industries. Key words: starch synthesis enzyme, gene expression, starch accumulation, starch granule distribution, starch gelatinization, potato tuber.

Síntese de amido e propriedades de gelatinização de tubérculos de batata com diferentes teores de amido

RESUMO: A biossintese é a única fonte de amido de batata que é uma importante matéria-prima para o processamento de alimentos, amido modificado e energia de biomassa. No entanto, não está claro sobre a evolução da síntese do amido com o desenvolvimento do tubérculo na batata. O presente estudo teve como objetivo avaliar as diferenças nas propriedades de síntese e gelatinização do amido de tubérculos de batata com diferentes teores de amido. Em relação às cultivares de médio e baixo teor de amido, as cultivares de alto teor de amido apresentaram expressão do gene SBEII, atividade enzimática AGPase e SSS e teor de amido total significativamente maiores após o estágio intermediário de acúmulo de amido, bem como menor tamanho médio dos grânulos de amido durante todo o processo de desenvolvimento do tubérculo, maior temperatura de colagem antes dos estágios finais de crescimento do tubérculo e menor temperatura de colagem após o estágio intermediário de acúmulo de amido. A análise de trilha mostrou que, após o estágio intermediário de acúmulo de amido, os efeitos na gelatinização do amido de cultivares com alto, médio e baixo teor de amido representaram a atividade da enzima de síntese de amido $>$ acúmulo de amido > distribuição de grânulos de amido > expressão gênica de enzima de síntese de amido; expressão gênica de enzima de síntese de amido > atividade da enzima de síntese de amido $>$ acúmulo de amido $>$ distribuição de grânulos de amido; expressão gênica da enzima de sintese de amido > distribuição de grânulos de amido > atividade de síntese de amido > acúmulo de amido, respectivamente. No estudo, as fases existentes na biossintese do amido do tubérculo de batata, e a qualidade do amido e seu processo de formação foram diferentes entre as variedades com diferentes teores de amido. As descobertas podem contribuir para a aplicação de amido e as indústrias de batata. Palavras-chave: enzima de síntese de amido, expressão genética, acumulação de amido, distribuição de grânulos de amido, gelatinização do amido, tubérculo de batata.

\section{INTRODUCTION}

Potato (Solanum tuberosum L.) is the fourth most important food crop in the world, with a total planting area of 20 million hectares and a total yield of 400 million tons globally per annum, following wheat, rice and corn. In recent years, China has undergone remarkable growth in potato production over the last two decades and become the largest producer of potatoes in the world, with a total

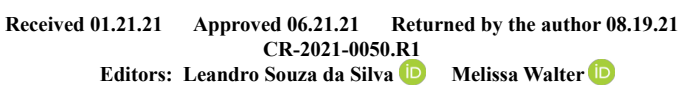


planting area of 5.6 million hectares and a total yield of 97 million tons (CHINA NATIONAL BUREAU OF STATISTICS, 2011-2020). Potato has now been elevated to one of the most important staple food for domestic food security in China (SU \& WANG, 2019).

Starch biosynthesis is accomplished by the coordination and interaction of various key enzymes with conservative functions, such as ADP glucose pyrophosphorylase (AGPase), soluble starch synthetase (SSS), granule bound starch synthetase (GBSS) and starch branching enzyme (SBE). When antisense inhibition reduced the expression of AGPase, MÜLLER-RÖBER et al. (1992) reported that the starch content of transgenic potato tuber was $4-35 \%$ lower than that of wild type. Using patatin promoter drove mutant gene $g l g c-16$ of AGPase, STARK et al. (1992) found that the starch content of transgenic potato plants increased by $35 \%$ compared with that of wild type. The down-regulation of AGPase in potato tubers resulted in GBSSI expression (LLOYD et al. 1999). Above reports confirmed that AGPase was the key and rate-limiting enzyme in starch synthesis of potato. HOVENKAMP-HERMELINK et al. (1987) reported that amylose accumulation was significantly decreased in both potato mutant deficient in GBSSI and transgenic potato plant expressing RNAi construct targeting GBSSI. Further studies indicated that GBSS not only regulates amylase biosynthesis, but is also involved in the syntheses of amylopectin (RAL et al., 2006) and super long chain of amylopectin (FULTON et al., 2002). In potato, SSS are mainly referred to SSII and SSIII, which plays a key role in the biosynthesis of amylopectin. EDWARDS et al. (1999) showed that the loss of SSII reduced the synthesis of medium length amylopectin. The over expression of SSIII resulted in the production of abundant small starch granules and which often have cracks in their central position (MARSHALL et al., 1996). The SBE is consisting of two distinct types, SBEI and SBEII, which catalyze the branching of amylopectin. The starch granules structure altered featuring the increase of amylopectin chain length and increase in amylose content when the expression of SBEII was inhibited in potato (JOBLING et al., 1999). While the inhibition of SBEI did not increase amylose content significantly (SAFFORD et al., 1998), the simultaneous down-regulation of both SBEI and SBEII led to $75 \%$ increase of amylose content in potato (SCHWALL et al. 2000).

A number of other enzymes, such asisoamylase (ISA), starch phosphoylase (PHO) and glucan water dikinase (GWD) have also been reported to be involved in starch synthesis of potato
(FERREIRA et al., 2017; ALBRECHT et al., 2001; DUWENIG et al., 1997; DAVIS et al., 2003). It appears clear that ISA is attributable for the spiral structure potato amylopectin and ease to crystallize (DELATTE et al., 2005; BUSTOS et al., 2004; FERREIRA et al., 2017), but the functional roles of Pho and GWD remain largely elusive.

Indirect regulation of potato starch synthesis has also been reported. The over-expression of $S O D$ and $A P X$ improved starch accumulation in transgenic potato tubers (SHAFI et al., 2017). MA et al. (2013) showed that the synthesis and accumulation of starch in potato tubers was enhanced by spraying 4-6 $\mathrm{g} \cdot \mathrm{L}^{-1}$ borax which primarily increased the activities of sucrose invertase and synthase hence promoting the synthesis of sucrose and reducing sugars.

It has been well documented that the effect of agricultural measures, such as film mulching and fertilizer application, on the starch synthesis in potato (FENG et al., 2019; WU et al., 2019; YANG et al., 2013). However, the genotypic effect on starch synthesis is generally lacking.

Starch gelatinization is an important index for the quality evaluation in potato and has significant impact on food processing (BAO et al., 2004), which is significantly affected by both genotype and environmental conditions (water, temperature, nutritional status, etc.) (COVENTRY et al., 2011). There are a number of studies on the effect of environmental conditions on the physical and chemical properties and structural characteristics in the postharvest potato starch (CHEN et al., 2015; GALKOWSKA., 2014; ZHANG et al., 2018; QIU et al., 2015). However, the impact of environmental factors on starch quality is relatively scarce in potato, whereas most of such studies were carried out in cereal crops, such as wheat (ZHOU et al., 2018), rice (CAO et al., 2018) and corn (SHI et al., 2018).

In this study, we utilized a number of elite potato varieties which are widely grown in the major potato production areas in China, which are grouped into three types based on their starch content (high, medium and low). We analyzed gelatinization characteristics and its determining factors, such as gene expression and activity of a number of starch synthesis key enzymes, starch accumulation, and starch granule distribution during the period of potato tuber formation. Further, the path analysis of gelatinization characteristics and determining factors was carried out, which may not only shed more light on the molecular mechanisms of starch biosynthesis but also provide a practical guide for potato breeding aiming for high starch content and high quality traits, in 
addition to the improvement of cultivation measures suitable for enhancement of starch traits in potato.

\section{MATERIALS AND METHODS}

\section{Site description}

In 2017-2018, the field trial was conducted in the experimental station of Academy of Agricultural and Forestry Sciences, Qinghai University $\left(36.73^{\circ} \mathrm{N}\right.$, $\left.101.75^{\circ} \mathrm{E}\right)$, located in the northeast part of QinghaiTibet Plateau, with an altitude of $2339 \mathrm{~m}$, with a typical semi-arid climate of continental plateau. The annual rainfall in this region is about $380 \mathrm{~mm}$ and $70 \%$ occurs in the period from June to September. The experimental station has an average sunshine period of $1939.7 \mathrm{~h}$, an average temperature of $7.6^{\circ} \mathrm{C}$., an average annual evaporation of $1363.6 \mathrm{~mm}$, and a frost free period of $180 \mathrm{~d}$. The soil texture belongs to the chestnut soil category and the topsoil contains $17.2 \mathrm{mg} \cdot \mathrm{kg}^{-1}$ organic matter $(\mathrm{pH} 8.1), 147.1 \mathrm{mg} \cdot \mathrm{kg}^{-1}$ alkali hydrolyzed nitrogen, $21.0 \mathrm{mg} \cdot \mathrm{kg}^{-1}$ available phosphorus, $158.9 \mathrm{mg} \cdot \mathrm{kg}^{-1}$ available potassium.

\section{Experimental design}

Nine potato varieties with different starch content were chosen, among which the high starch content varieties ( $\geq 18 \%$ tuber starch content, HV) included Qingshu 9, Qingshu 2, Datongliwaihuang; and the medium starch content varieties (14-18\% tuber starch content, MV) included Jinshu 16, Tongshu 29, Tongshu 20; and the low starch content varieties $(\leq 14 \%$ tuber starch content, $L V)$ included Tongshu 28, Minshu 1, Kexin 1.

Field plot was designed with single factor random block arrangement and three repeats were made in two consecutive years. The plot area was 5 $\mathrm{m} \times 3.5 \mathrm{~m}=17.5 \mathrm{~m}^{2}$, with five rows and $70 \mathrm{~cm}$ row spacing. The planting density of each plot was 4.28 $\times 10^{4}$ plants $\cdot \mathrm{hm}^{-2} .300 \mathrm{~kg} \cdot \mathrm{hm}^{-2}$ diamine, $225 \mathrm{~kg} \cdot \mathrm{hm}^{-2}$ urea and $150 \mathrm{~kg} \cdot \mathrm{hm}^{-2}$ potassium sulfate were applied as fertilizer prior to sowing. Other field managements were carried out according to the National Potato Variety Regional Test. Soil prepared on April 23, 2017 and April 25, 2018, sowed on April 24, 2017 and April 26, 2018, and harvested on October 13, 2017 and September 27, 2018, respectively. Irrigation was not provided throughout the entire growing season.

\section{Measurement method Sampling}

During the period from ultimate swelling of stolon to harvest, the samples were taken with time sequence, and the specific sampling periods were as follows: the late stage of tuber formation (the first inflorescence starting to bloom) (S1), the early stage of tuber growth (the flowering stage) (S2), the late stage of tuber growth (the start of senescence of the stem and leaf) (S3), the middle stage of starch accumulation (about $1 / 3$ of the stem and leaf at the basal of the plant turning yellow) (S4), the late stage of starch accumulation (about 2/3 of the stem and leaf at the basal of the plant turning yellow) (S5), the maturity stage (all the stem and leaf of the plant above ground turning yellow) (S6). Two plants with average growth were selected for sampling in each repeated plot of each treatment, and all the tubers of each sampling plant were collected for analyses.

Following the removal of the residual soil, the sampled potato tubers with the similar size, were cut out three potato chips in $0.5 \mathrm{~cm}$ thickness from the top, middle and bottom respectively. Such chips were further cut into cubes in the similar sizes of 0.1 $0.2 \mathrm{~cm}^{2}$, and mixed prior to weighing out $4.0 \mathrm{~g}$ and stored in an ultra-low temperature refrigerator at -80 ${ }^{\circ} \mathrm{C}$, among which $2.0 \mathrm{~g}$ was used to measure the gene expression of AGPase, SSII, SSIII, GBSSI, SBEI and $S B E I I$, while the rest $2.0 \mathrm{~g}$ was used to measure the enzyme activity of AGPase, SSS, GBSS and SBE.

The part of remaining potato tubers was chopped, dried and crushed to determine the total starch content of potato tubers. Starch was extracted from all the remaining potato tubers by the natural sedimentation method, and was used to determine the amylose content, starch granule distribution and starch gelatinization characteristics. The specific steps of starch extraction were as follows: cleaning tuber $\rightarrow$ removing epidermis $\rightarrow$ crushing into homogenate by wall breaker $\rightarrow$ filtered by 80 mesh sieve ( 2 to 3 times) $\rightarrow$ sedimentation (natural sedimentation for 6-7 h and then water exchange for sedimentation again) $\rightarrow$ vacuum filtration $\rightarrow$ natural drying $\rightarrow$ starch.

Gene expression of key enzymes in starch synthesis (FF1) Total RNA and genomic DNA were extracted from the tuber samples stored in $-80{ }^{\circ} \mathrm{C}$ refrigerator as previously described (HUANG et al., 2014). The first strand cDNA was synthesized by RNA reverse transcription using $2 \mu \mathrm{g}$ RNA (PrimeScript RT Reagent Kit, Takara Bio, Inc., Japan). Oligo primers for quantitative reverse transcription polymerase chain reaction (qRT-PCR) were designed by using Primer Premier 5.0 software (http://www.premierbiosoft.com/primerdesign/) based on the gene sequence in National Center for Biotechnology Information (NCBI) (Table 1). Using first strand cDNA as template, tublin1 as internal 
Table 1 - Target gene and sequence of qRT-PCR primers.

\begin{tabular}{lcc}
\hline Gene name & Forward primer $\left(5^{\prime}-3^{\prime}\right)$ & Reverse primer $\left(5^{\prime}-3^{\prime}\right)$ \\
\hline Tublin 1 & GTCAGTCTGGTGCTGGTAATAA & TCTCAGCCTCCTTCCTTACA \\
A GPase & TTCCTTCCACCAACCAAGATAG & CACTATGGAGTGTTCCACAGAA \\
SSII & CAACAGGACCTACTTCAACAGA & CTACCACTCCCACCATCATAAG \\
SSIII & GTCACCTGTTCGTGTATCATCT & CCACTCTCTTCCGATCTCTTTG \\
SBSSI $B E I$ & CTTGCGTTTGCTGAGATGATAAA & CAGAAGCTCCTAAGCCCAATAG \\
SBEII & GCGAACATGTGTGGCTTATTAC & TCTCGTCACTCTCCTCGATATT \\
\hline
\end{tabular}

reference gene, qRT-PCR was carried out according to Tag SYBR ${ }^{\circledR}$ Green qPCR Kit (Bio-Rad Laboratories, Inc., USA). Following the amplification reaction, the dissolution curve was drawn to ensure the primer specificity. Each sample was repeated three times, and the relative expression of target gene was calculated according to the $\Delta C t$ method (PFAFFL., 2001).

\section{Activity of key enzymes in starch synthesis (FF2)}

Crude enzyme solution was prepared for assaying AGPase, SSS and GBSS using $1.0 \mathrm{~g}$ potato tuber which was grinded into powder, and mixed into a $800 \mu \mathrm{L}$ of extracted solution $\left(50 \mathrm{mmol} \cdot \mathrm{L}^{-1} \mathrm{HEPES}\right.$, pH 7.2-7.4, $5 \mathrm{mmol} \cdot \mathrm{L}^{-1}$ EDTA, $1 \mathrm{mmol} \cdot \mathrm{L}^{-1} \mathrm{DTT}, 2$ $\mathrm{mmol} \cdot \mathrm{L}^{-1} \mathrm{KCl}, 1 \%$ pvp-40). Following homogenation and the samples were centrifuged at $10,000 \mathrm{r} \cdot \mathrm{min}^{-1}$ for $30 \mathrm{~min}$, and the supernatant was used for the crude enzyme activity determination of AGPase and SSS. The precipitate obtained by centrifugation was further washed with $800 \mu \mathrm{L}$ extraction solution prior to resuspension in the extraction medium as the crude enzyme solution for the determination of GBSS enzyme activity. The enzyme assays were carried out as described by NAKAMURA et al. (1989).

For the crude enzyme assay for SBE, $1.0 \mathrm{~g}$ of potato tuber was grinded in $800 \mu \mathrm{L}$ of extracted solution (50 mmol $\cdot \mathrm{L}^{-1} \mathrm{HEPES}-\mathrm{NaOH}, \mathrm{pH} 7.5,5 \mathrm{mmol} \cdot \mathrm{L}^{-1}$ EDTA, $1 \mathrm{mmol} \cdot \mathrm{L}^{-1} \mathrm{DTT}, 2 \mathrm{mmol} \cdot \mathrm{L}^{-1} \mathrm{KCl}, 1 \%$ pvp-40). Following homogenization, the grinded samples were centrifuged at $15,000 \mathrm{r} \cdot \mathrm{min}^{-1}$ for $15 \mathrm{~min}$ at $4{ }^{\circ} \mathrm{C}$. The supernatant was then used as the crude enzyme solution for assaying the SBE enzyme activity as previously described (LI et al., 1997; CHENG et al., 2001).

\section{Starch accumulation (FF3) \\ Total starch content}

The total starch content of potato was determined by the method of TANG et al. (2015). Briefly, the extracted starch samples were dissolved in perchloric acid, then color was developed at constant volume, and the absorption values of $660 \mathrm{~nm}$ were determined with distilled water as control. The total starch content was calculated using the following formula:

Total starch content $(\%)=R /(0.1 \times 0.01 \times 0.05 \times$ $\left.10^{6}\right) \times 100 \quad(1)$

Where $R$ value was the concentration calculated from the standard curve. Each sample was measured three times.

\section{Amylose content}

Approximately $2 \mathrm{mg}$ of the extracted starch samples were transferred into a beaker with $0.5 \mathrm{~mL}$ of $35 \%$ perchloric acid solution. Following a brief mixing, the starch samples were completely dissolved by adding $8 \mathrm{~mL}$ of distilled water. Blank samples without starch were prepared as the control. $600 \mu \mathrm{L}$ of the prepared sample solutions were transferred into each of the two colorimetric tubes, prior to the successive addition of $300 \mu \mathrm{L}$ of iodine solution and $1800 \mu \mathrm{L}$ of distilled water. Following thorough mixing, the absorption value was measured at $550 \mathrm{~nm}$ and $618 \mathrm{~nm}$, respectively, and repeated three times (Tang et al. 2015). The amylose content was calculated using the following formula:

Amylose content $(\%)=(3.5-5.1 \times R) /(10.4 \times R$ $19.9) \times 100 \quad(2)$

Where $R=$ absorbance at $618 \mathrm{~nm} /$ absorbance at $550 \mathrm{~nm}$ (3)

The amylopectin content and the amylose/ amylopectin ratio were calculated as follows:

Amylopectin content (\%) = 1 - amylose content (\%) (4) Amylose/amylopectin ratio = amylose content (\%) / amylopectin content (\%)

\section{Starch granule distribution (FF4)}

The distribution of starch granule was determined by using Mastersizer 2000 Laser Particle Sizer (Malvern Company, UK). Approximately 
3-5 g of starch were evenly dissolved it in $30 \mathrm{~mL}$ of anhydrous ethanol, and transferred into a beaker with $500 \mathrm{~mL}$ of anhydrous ethanol drop by drop. The starch granule size was then measured with ultrasound being maintained the opacity at about $75 \%$. The measurement was repeated for three times. The results of particle size analysis were expressed as the median and boundary size of starch particles which were defined as follows. The median diameter was termed as the average particle size, and recorded as $\mathrm{d}(0.5)$ in the analysis software. The boundary size of particles was called the distribution width, indicated the range of particle size distribution about treated samples. Dispersion meant distribution width divided by average particle size.

\section{Starch gelatinization properties}

Starch gelatinization properties were determined by RVA-TecMaster Rapid Viscosity Analyzer (Perten Company, Sweden). The measurement was repeated for 2-3 times, and the pasting temperature, viscosity at different stage, breakdown and setback value were recorded.

\section{Statistical analysis}

Microsoft Excel 2007 and SAS v8.0 were used for data processing and statistical analysis. Origin 7.5 was used for drawing. Duncan method was used for multiple comparison between samples $(a=0.01)$. Path analysis took starch gelatinization properties as the dependent variables, and took FF1, FF2, FF3 and FF4 as the independent variables.

\section{RESULTS}

\section{The existence of turning points}

During potato tuber development, there were turning points in activity and gene expression of key enzymes in starch synthesis, starch accumulation, starch granule distribution and starch gelatinization properties between S3-S4 in potato with different starch content (Figure 1-2, Table 2-4).

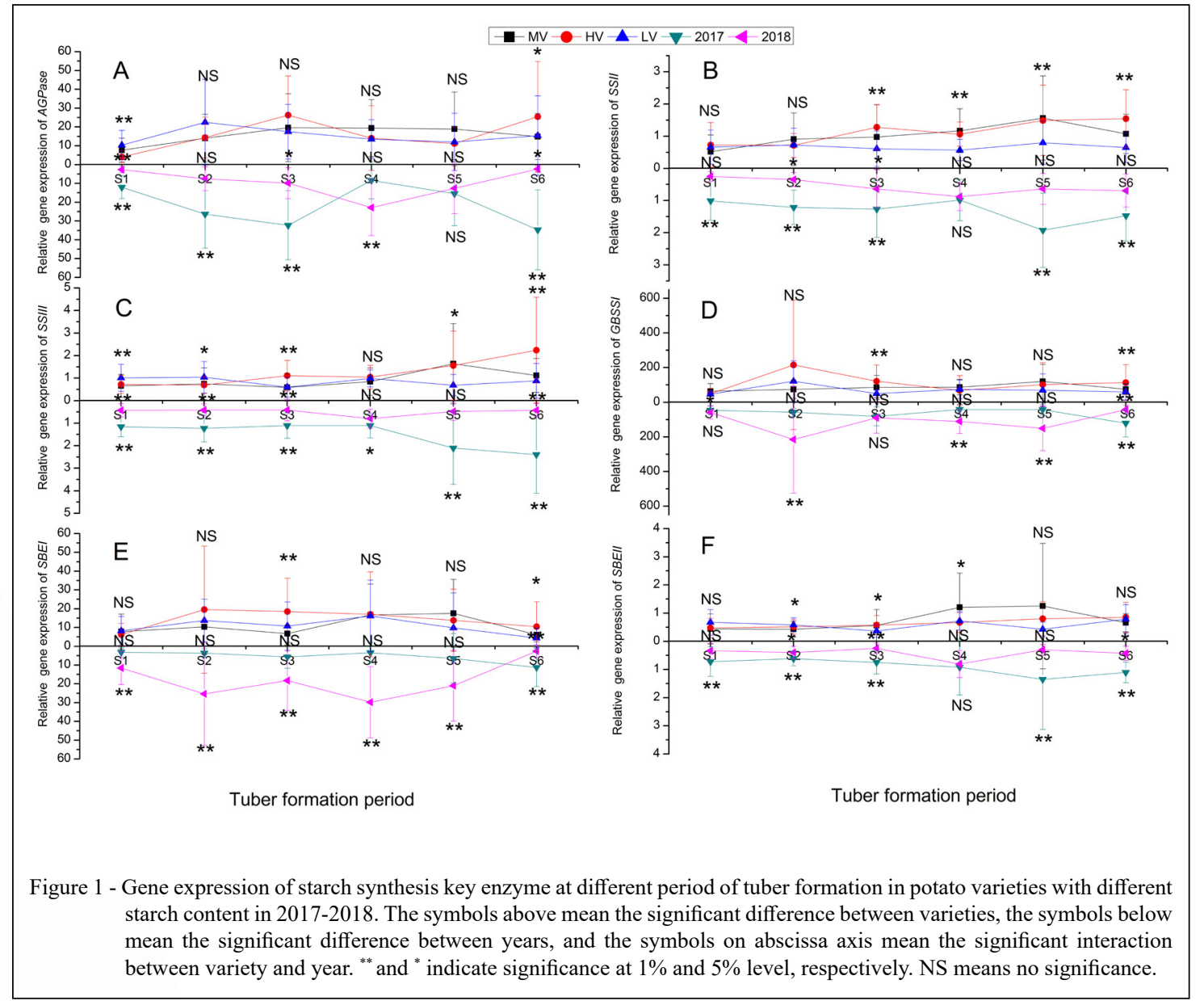

Ciência Rural, v.52, n.4, 2022. 
Differences of starch synthesis and gelatinization properties

Gene expression of starch synthesis key enzyme

During S1-S3, the relative gene expression of $S B E I$ represented MV $>$ LV $>\mathrm{HV}(P<0.01$, Figure $1 \mathrm{E})$; however, there were all no significant differences between $\mathrm{HV}, \mathrm{MV}$ and $\mathrm{LV}$ in the relative gene expression of AGPase (Figure 1A), SSII (Figure 1B), SSIII (Figure $1 \mathrm{C}$ ), GBSSI (Figure 1D) and SBEII (Figure 1F).

During S4-S6, the relative gene expression of SSII, SSIII, SBEII represented MV $>\mathrm{HV}>\mathrm{LV}(P<$ 0.01 , Figure.1B), MV $>\mathrm{HV}>\mathrm{LV}(P<0.01$, Figure $1 \mathrm{C})$, $\mathrm{HV}>\mathrm{MV}>\mathrm{LV}(P<0.01$, Figure $1 \mathrm{~F})$; however, there were all no significant differences between $\mathrm{HV}, \mathrm{MV}$ and $\mathrm{LV}$ in the relative gene expression of AGPase (Figure 1A), GBSSI (Figure 1D) and SBEI (Figure 1E).

\section{Activity of starch synthesis key enzyme}

During S1-S3, the activity of AGPase, SSS, SBE represented MV $>\mathrm{HV}>\mathrm{LV}(P<0.01$,
Figure 2A), HV $>\mathrm{MV}>\mathrm{LV}(P<0.01$, Figure 2B), MV $>$ LV $>\mathrm{HV}(P<0.01$, Figure 2D); however, there was no significant difference between $\mathrm{HV}, \mathrm{MV}$ and LV in the activity of GBSS (Figure 2C).

During S4-S6, the activity of AGPase, SSS represented $\mathrm{HV}>\mathrm{MV}>\mathrm{LV}(P<0.05$, Figure $2 \mathrm{~A})$, $\mathrm{HV}>\mathrm{MV}>\mathrm{LV}(P<0.01$, Figure $2 \mathrm{~B})$; however, there were all no significant differences between $\mathrm{HV}, \mathrm{MV}$ and LV in the activity of GBSS (Figure 2C) and SBE (Figure 2D).

\section{Starch accumulation}

During S1-S3, the total starch content represented $\mathrm{MV}>\mathrm{LV}>\mathrm{HV}\left(P<0.01\right.$, Table $\left.2^{\mathrm{a}}\right)$; however, there were all no significant differences between $\mathrm{HV}, \mathrm{MV}$ and LV in the amylose content (Table $2^{\mathrm{b}}$ ) and amylose/amylopectin ratio (Table $2^{\mathrm{c}}$ ).

During S4-S6, the total starch content represented HV $>\mathrm{LV}>\mathrm{MV}\left(P<0.05\right.$, Table $\left.2^{\mathrm{a}}\right)$, however, there were all no significant differences

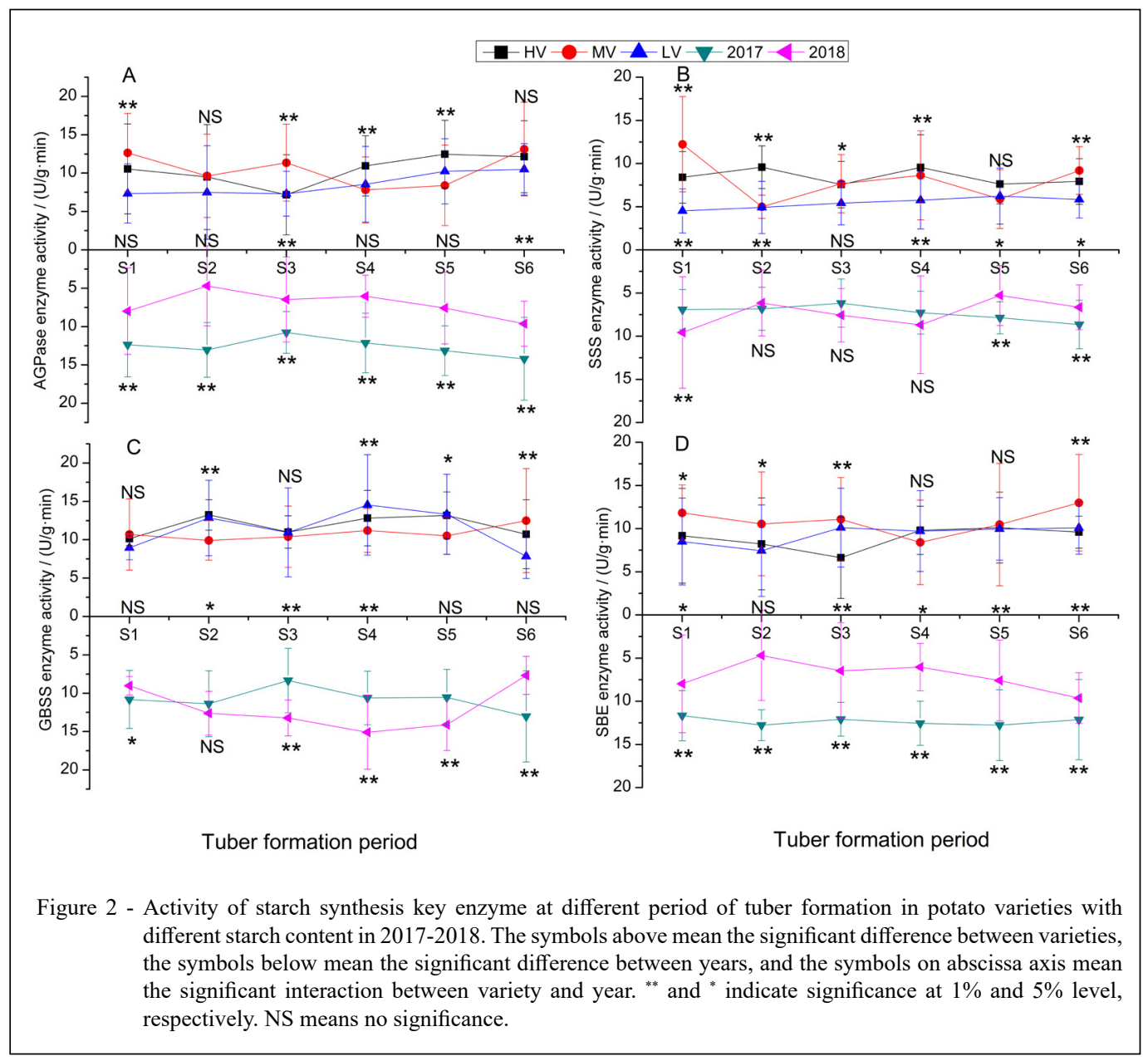

Ciência Rural, v.52, n.4, 2022. 
Table 2 - Starch accumulation at different period of tuber formation in potato varieties with different starch content in $2017-2018$.

\begin{tabular}{|c|c|c|c|c|c|c|}
\hline \multirow{2}{*}{$\begin{array}{l}\text { Tuber } \\
\text { formation } \\
\text { period }\end{array}$} & \multicolumn{3}{|c|}{----------------------------------'Variety---------------------------- } & ------ & ar------------------- & \multirow[t]{2}{*}{ Interaction } \\
\hline & HV & MV & LV & 2017 & 2018 & \\
\hline \multicolumn{7}{|c|}{ 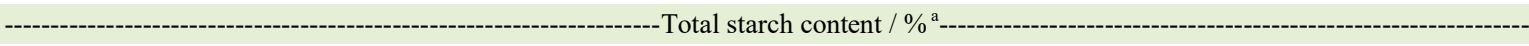 } \\
\hline S1 & $10.78 \pm 4.06 \mathrm{Aa}$ & $12.33 \pm 3.50 \mathrm{Aa}$ & $12.34 \pm 3.52 \mathrm{Aa}$ & $13.59 \pm 3.62 \mathrm{Aa}$ & $10.05 \pm 2.90 \mathrm{Bb}$ & NS \\
\hline $\mathrm{S} 2$ & $11.00 \pm 3.53 \mathrm{Cc}$ & $17.52 \pm 4.50 \mathrm{Aa}$ & $14.48 \pm 5.05 \mathrm{Bb}$ & $16.61 \pm 5.10 \mathrm{Aa}$ & $12.06 \pm 4.01 \mathrm{Bb}$ & NS \\
\hline S3 & $12.83 \pm 3.89 \mathrm{Aa}$ & $13.22 \pm 5.87 \mathrm{Aa}$ & $14.53 \pm 4.87 \mathrm{Aa}$ & $16.10 \pm 4.60 \mathrm{Aa}$ & $10.95 \pm 3.75 \mathrm{Bb}$ & NS \\
\hline S4 & $18.04 \pm 4.32 \mathrm{Aa}$ & $12.15 \pm 3.95 \mathrm{Bb}$ & $12.25 \pm 4.26 \mathrm{Bb}$ & $14.23 \pm 2.74 \mathrm{Aa}$ & $14.07 \pm 6.51 \mathrm{Aa}$ & ** \\
\hline S5 & $16.58 \pm 4.60 \mathrm{Aa}$ & $17.54 \pm 3.20 \mathrm{Aa}$ & $18.01 \pm 4.33 \mathrm{Aa}$ & $19.18 \pm 4.28 \mathrm{Aa}$ & $15.57 \pm 2.91 \mathrm{Bb}$ & * \\
\hline S6 & $14.37 \pm 4.00 \mathrm{Bb}$ & $12.61 \pm 4.49 \mathrm{Cc}$ & $16.18 \pm 2.71 \mathrm{Aa}$ & $14.85 \pm 2.62 \mathrm{Aa}$ & $13.93 \pm 5.06 \mathrm{Aa}$ & NS \\
\hline \multicolumn{7}{|c|}{ 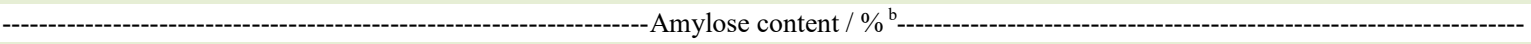 } \\
\hline S1 & $12.43 \pm 4.08 \mathrm{Aa}$ & $13.14 \pm 6.90 \mathrm{Aa}$ & $11.65 \pm 5.61 \mathrm{Aa}$ & $13.03 \pm 4.27 \mathrm{Aa}$ & $11.78 \pm 6.65 \mathrm{Aa}$ & ** \\
\hline $\mathrm{S} 2$ & $11.32 \pm 6.79 \mathrm{Aa}$ & $11.68 \pm 5.12 \mathrm{Aa}$ & $10.11 \pm 4.95 \mathrm{Aa}$ & $13.80 \pm 4.34 \mathrm{Aa}$ & $8.27 \pm 5.44 \mathrm{Bb}$ & * \\
\hline S3 & $10.60 \pm 4.70 \mathrm{Bb}$ & $8.76 \pm 1.94 \mathrm{Cc}$ & $13.36 \pm 5.24 \mathrm{Aa}$ & $10.29 \pm 3.29 \mathrm{Aa}$ & $11.52 \pm 5.54 \mathrm{Aa}$ & ** \\
\hline S4 & $14.39 \pm 6.28 \mathrm{Aa}$ & $16.08 \pm 15.67 \mathrm{Aa}$ & $17.52 \pm 13.75 \mathrm{Aa}$ & $18.31 \pm 9.58 \mathrm{Aa}$ & $13.69 \pm 14.51 \mathrm{Aa}$ & * \\
\hline S5 & $25.26 \pm 14.49 \mathrm{Aa}$ & $12.68 \pm 9.46 \mathrm{Bb}$ & $11.19 \pm 8.37 \mathrm{Bb}$ & $20.17 \pm 8.29 \mathrm{Aa}$ & $12.58 \pm 15.02$ & * \\
\hline S6 & $12.47 \pm 5.84 \mathrm{Bb}$ & $19.08 \pm 8.09 \mathrm{Aa}$ & $10.72 \pm 6.73 \mathrm{Cc}$ & $15.26 \pm 7.87 \mathrm{Aa}$ & $12.92 \pm 7.54 \mathrm{Aa}$ & * \\
\hline \multicolumn{7}{|c|}{ 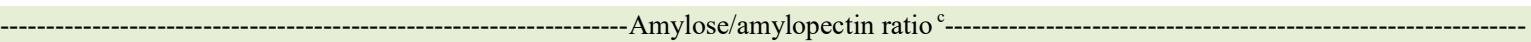 } \\
\hline S1 & $0.144 \pm 0.056 \mathrm{Aa}$ & $0.159 \pm 0.097 \mathrm{Aa}$ & $0.136 \pm 0.075 \mathrm{Aa}$ & $0.152 \pm 0.059 \mathrm{Aa}$ & $0.141 \pm 0.092 \mathrm{Aa}$ & ** \\
\hline S2 & $0.134 \pm 0.090 \mathrm{Aa}$ & $0.136 \pm 0.065$ Aa & $0.115 \pm 0.062 \mathrm{Aa}$ & $0.162 \pm 0.055 \mathrm{Aa}$ & $0.094 \pm 0.073 \mathrm{Bb}$ & * \\
\hline S3 & $0.122 \pm 0.060 \mathrm{Bb}$ & $0.096 \pm 0.023 \mathrm{Cc}$ & $0.158 \pm 0.069 \mathrm{Aa}$ & $0.116 \pm 0.040 \mathrm{Aa}$ & $0.135 \pm 0.073 \mathrm{Aa}$ & ** \\
\hline S4 & $0.174 \pm 0.088$ Aa & $0.264 \pm 0.392 \mathrm{Aa}$ & $0.252 \pm 0.240 \mathrm{Aa}$ & $0.246 \pm 0.182 \mathrm{Aa}$ & $0.214 \pm 0.336 \mathrm{Aa}$ & $*$ \\
\hline S5 & $0.456 \pm 0.545 \mathrm{Aa}$ & $0.158 \pm 0.129 \mathrm{Bb}$ & $0.136 \pm 0.112 \mathrm{Bb}$ & $0.268 \pm 0.142 \mathrm{Aa}$ & $0.233 \pm 0.486 \mathrm{Aa}$ & NS \\
\hline S6 & $0.147 \pm 0.076 \mathrm{Bb}$ & $0.247 \pm 0.121 \mathrm{Aa}$ & $0.127 \pm 0.096 \mathrm{Cc}$ & $0.190 \pm 0.115 \mathrm{Aa}$ & $0.157 \pm 0.107 \mathrm{Aa}$ & NS \\
\hline
\end{tabular}

Note: Different large and small letters in the same row indicate significant difference among varieties at 0.01 and 0.05 level, respectively. ${ }^{* *}$ and ${ }^{*}$ indicate significance in interaction at $1 \%$ and $5 \%$ level, respectively. NS means no significance in interaction.

between HV, MV and LV in the amylose content $\left(\right.$ Table $2^{\mathrm{b}}$ ) and amylose/amylopectin ratio (Table $2^{\mathrm{c}}$ ).

\section{Starch granule distribution}

During S1-S3, the average particle size represented LV $>$ MV $>$ HV $(P<0.01$, Table $\left.3^{a}\right)$;however, there was no significant difference between HV, MV and LV in dispersion (Table $3^{\mathrm{b}}$ ).

During S4-S6, the average particle size represented MV $>\operatorname{LV}>\operatorname{HV}\left(P<0.05\right.$, Table $\left.3^{\mathrm{a}}\right)$; however, there was no significant difference between $\mathrm{HV}, \mathrm{MV}$ and LV in dispersion (Table $3^{\mathrm{b}}$ ).

\section{Starch gelatinization properties}

During S1-S3, the peak viscosity, though viscosity, breakdown value, final viscosity, pasting temperature represented $\mathrm{MV}>\mathrm{LV}>\mathrm{HV}(P<0.01$, Table $\left.4^{\mathrm{a}}\right), \mathrm{MV}>\mathrm{LV}>\mathrm{HV}\left(P<0.01\right.$, Table $\left.4^{\mathrm{b}}\right)$, MV $>\mathrm{HV}>\mathrm{LV}\left(P<0.05\right.$, Table $\left.4^{\mathrm{c}}\right), \mathrm{MV}>\mathrm{LV}>\mathrm{HV}(P<$ 0.01 , Table $\left.4^{\mathrm{d}}\right), \mathrm{HV}>\mathrm{MV}>\operatorname{LV}\left(P<0.01\right.$, Table $\left.4^{\mathrm{f}}\right)$; however, there was no significant difference between HV, MV and LV in setback value (Table $4^{\mathrm{e}}$ ).

During S4-S6, the pasting temperature represented LV $>\mathrm{MV}>\mathrm{HV}\left(P<0.01\right.$, Table $\left.4^{\mathrm{f}}\right)$; however, there were all no significant differences between HV, MV and LV in peak viscosity (Table $4^{a}$ ), though viscosity $\left(\right.$ Table $\left.4^{b}\right)$, breakdown value (Table $4^{c}$ ), final viscosity (Table $4^{d}$ ) and setback value (Table $4^{\mathrm{e}}$ ).

\section{Path analysis}

With the development of tuber, the effects of FF1-4 on starch gelatinization properties were significantly different between HV, MV and LV (Table 5). During S1-S3, the effects on starch gelatinization properties of $\mathrm{HV}, \mathrm{MV}$ and $\mathrm{LV}$ represented FF2 $>$ FF1 $>$ FF3 $>$ FF4 $\left(\right.$ Table $5^{\mathrm{a}}$ ), FF2 $>$ FF1 $>$ FF3 $>$ FF4 (Table $5^{\text {b }}$ ), FF2 $>$ FF3 $>$ FF4 $>$ FF1 $\left(\right.$ Table $5^{c}$ ), respectively. However, during S4-S6, the effects on starch gelatinization of $\mathrm{HV}, \mathrm{MV}$ and $\mathrm{LV}$ represented FF2 $>$ FF3 $>$ FF4 $>$ FF1 $\left(\right.$ Table $5^{d}$ ), FF1> 
Table 3 - Starch granule distribution at different period of tuber formation in potato varieties with different starch content in $2017-2018$.

\begin{tabular}{|c|c|c|c|c|c|c|}
\hline \multirow{2}{*}{$\begin{array}{l}\text { Tuber } \\
\text { formation } \\
\text { period }\end{array}$} & \multicolumn{3}{|c|}{ 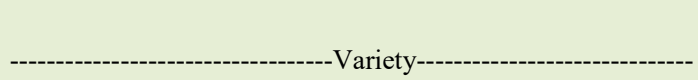 } & 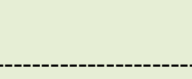 & 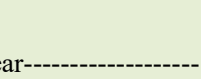 & Interaction \\
\hline & HV & MV & LV & 2017 & 2018 & \\
\hline \multicolumn{7}{|c|}{ 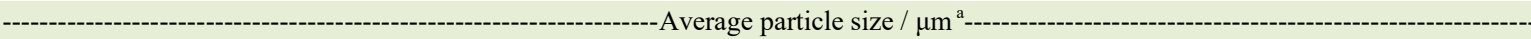 } \\
\hline S1 & $18.49 \pm 1.59 \mathrm{Bb}$ & $25.84 \pm 3.77 \mathrm{Aa}$ & $27.85 \pm 4.37 \mathrm{Aa}$ & $24.96 \pm 5.89 \mathrm{Aa}$ & $23.16 \pm 4.54 \mathrm{Ab}$ & ** \\
\hline $\mathrm{S} 2$ & $23.26 \pm 3.07 \mathrm{Cc}$ & $28.66 \pm 3.72 \mathrm{Bb}$ & $31.18 \pm 5.95 \mathrm{Aa}$ & $27.89 \pm 4.53 \mathrm{Aa}$ & $27.51 \pm 6.36 \mathrm{Aa}$ & ** \\
\hline S3 & $28.37 \pm 4.35 \mathrm{Ab}$ & $31.58 \pm 3.89 \mathrm{Aa}$ & $31.30 \pm 4.47 \mathrm{Aa}$ & $32.40 \pm 3.68 \mathrm{Aa}$ & $28.44 \pm 4.24 \mathrm{Bb}$ & NS \\
\hline S4 & $30.93 \pm 4.18 \mathrm{Aa}$ & $32.93 \pm 3.99 \mathrm{Aa}$ & $33.39 \pm 2.64 \mathrm{Aa}$ & $31.85 \pm 3.50 \mathrm{Aa}$ & $32.98 \pm 3.99 \mathrm{Aa}$ & NS \\
\hline S5 & $34.08 \pm 4.53 \mathrm{Aa}$ & $34.69 \pm 3.46 \mathrm{Aa}$ & $35.80 \pm 4.44 \mathrm{Aa}$ & $32.99 \pm 3.87 \mathrm{Bb}$ & $36.73 \pm 3.59 \mathrm{Aa}$ & NS \\
\hline S6 & $35.77 \pm 3.30 \mathrm{Bb}$ & $38.53 \pm 2.77 \mathrm{Aa}$ & $35.15 \pm 2.85 \mathrm{Bb}$ & $37.14 \pm 3.24 \mathrm{Aa}$ & $35.83 \pm 3.24 \mathrm{Aa}$ & NS \\
\hline \multicolumn{7}{|c|}{ 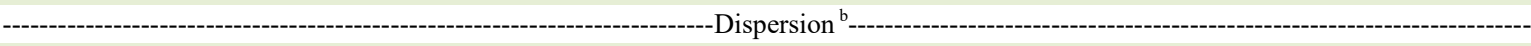 } \\
\hline S1 & $16.35 \pm 10.25 \mathrm{Aa}$ & $18.15 \pm 0.94 \mathrm{Aa}$ & $19.86 \pm 4.45 \mathrm{Aa}$ & $16.64 \pm 5.47 \mathrm{Aa}$ & $19.59 \pm 7.22 \mathrm{Aa}$ & NS \\
\hline $\mathrm{S} 2$ & $18.84 \pm 1.40 \mathrm{Aa}$ & $18.32 \pm 1.24 \mathrm{Aa}$ & $18.24 \pm 1.86 \mathrm{Aa}$ & $18.11 \pm 1.75 \mathrm{Aa}$ & $18.82 \pm 1.17 \mathrm{Aa}$ & NS \\
\hline S3 & $15.05 \pm 5.58 \mathrm{Ab}$ & $25.09 \pm 25.75 \mathrm{Aa}$ & $16.00 \pm 6.38 \mathrm{Ab}$ & $12.93 \pm 5.74 \mathrm{Bb}$ & $24.50 \pm 20.51 \mathrm{Aa}$ & $* *$ \\
\hline $\mathrm{S} 4$ & $18.73 \pm 2.12 \mathrm{Aa}$ & $16.99 \pm 6.61 \mathrm{Bb}$ & $12.76 \pm 7.33 \mathrm{Cc}$ & $14.89 \pm 6.83 \mathrm{Aa}$ & $17.43 \pm 5.44 \mathrm{Aa}$ & NS \\
\hline S5 & $17.67 \pm 1.72 \mathrm{Aa}$ & $14.76 \pm 5.59 \mathrm{Aa}$ & $17.69 \pm 8.38 \mathrm{Aa}$ & $14.25 \pm 6.20 \mathrm{Bb}$ & $19.16 \pm 4.61 \mathrm{Aa}$ & $* *$ \\
\hline S6 & $11.82 \pm 9.44 \mathrm{Bb}$ & $10.25 \pm 8.01 \mathrm{Bb}$ & $13.22 \pm 7.92 \mathrm{Aa}$ & $13.91 \pm 3.37 \mathrm{Bb}$ & $19.62 \pm 2.23 \mathrm{Aa}$ & ** \\
\hline
\end{tabular}

Note: Different large and small letters in the same row indicate significant difference among varieties at 0.01 and 0.05 level, respectively. ${ }^{* *}$ and ${ }^{*}$ indicate significance in interaction at $1 \%$ and $5 \%$ level, respectively. NS means no significance in interaction.

FF2 $>$ FF3 $>$ FF4 $\left(\right.$ Table $\left.5^{\mathrm{e}}\right), \mathrm{FF} 1>$ FF4 $>$ FF2 $>$ FF3 $\left(\right.$ Table $5^{\mathrm{f}}$ ), respectively.

\section{DISCUSSION}

\section{Interpretation of turning points}

So far, there has been no study to show that phases do exist in starch synthesis of potato during the process of tuber development. In this study for the first time, we reported that the values and trends for the activity and gene expression of starch synthesis key enzymes, starch accumulation, starch granule distribution and starch gelatinization properties were all significantly different before S3 and after S4 in potato tuber development (Figure 1-2, Table 2-4). We suggested that S3-S4 is the turning point of starch synthesis in potato tuber. We also believed that the starch synthesis is involved in the tuber morphogenesis before $\mathrm{S} 3$, and then it becomes the primary determining factor for the final morphology and content of tuber starch after S4. However, the initiation factors of transition period (S3-S4) need to be further studied.

\section{Implication of differences}

Most previous research explained the synthesis of high starch content was largely determined by efficacy of photosynthesis and assimilates transport in potato tuber (GUO et al., 1993; MEN et al., 1993a; MEN et al., 1993b; MEN et al., 1993c; MEN et al., 1994; LIU et al., 1994; MENG et al., 1999). In this study we have revealed that HV showed higher SBE2 gene expression (Figure 1F), AGPase enzyme activity (Figure 2A) and SSS enzyme activity (Figure 2B) compared with MV and LV after S4. Previous studies have shown that SBE2 was the main gene subtype controlling synthesis of amylopectin branches (SHIMADA et al., 2006; NIELSEN et al., 2002), AGPase enzyme catalyzed substrate synthesis of amylose and amylopectin (EMES \& NEUHAUS, 1997; GEIGENBERGER et al., 2005; TIESSEN et al., 2002), and SSS enzyme was responsible for amylopectin synthesis (DU et al., 2012). It could be seen that the efficient synthesis of amylopectin and its branches was largely attributable to the high level of starch accumulation in potato tubers after S4. Such a claim was strengthened by our further observation that HV accumulated higher level of starch than MV and LV when the growth period of tuber entered S4 (Table 2a).

Compared with MV and LV, HV showed larger average starch granule size during S1-S6 (MEN et al., 1993a), but smaller average starch granule size at harvest time according to the research of LOU et al. (2010). It could be seen that the relationship between 
Table 4 - Starch gelatinization properties at different period of tuber formation in potato varieties with different starch content in 2017 2018 .

\begin{tabular}{|c|c|c|c|c|c|c|}
\hline \multirow{2}{*}{$\begin{array}{l}\text { Tuber } \\
\text { formation } \\
\text { period }\end{array}$} & \multicolumn{3}{|c|}{---------------------------------------Variety------------------------------------ } & \multicolumn{2}{|c|}{---------------------Year------------------ } & \multirow[t]{2}{*}{ Interaction } \\
\hline & HV & MV & LV & 2017 & 2018 & \\
\hline \multicolumn{7}{|c|}{-1 } \\
\hline S1 & $406.6 \pm 220.9 \mathrm{Cc}$ & $2617.5 \pm 2077.5 \mathrm{Aa}$ & $2001.7 \pm 950.6 \mathrm{Bb}$ & $2340.6 \pm 1972.3 \mathrm{Aa}$ & $1010.0 \pm 661.9 \mathrm{Bb}$ & ** \\
\hline $\mathrm{S} 2$ & $1669.6 \pm 834.2 \mathrm{Bb}$ & $2766.5 \pm 431.9 \mathrm{Aa}$ & $2524.3 \pm 622.2 \mathrm{Aa}$ & $2315.6 \pm 935.4 \mathrm{Aa}$ & $2324.7 \pm 644.1 \mathrm{Aa}$ & NS \\
\hline S3 & $3121.3 \pm 968.1 \mathrm{Aa}$ & $3015.4 \pm 340.2 \mathrm{Aa}$ & $2797.5 \pm 451.7 \mathrm{Aa}$ & $3296.7 \pm 733.6 \mathrm{Aa}$ & $2659.4 \pm 332.6 \mathrm{Bb}$ & NS \\
\hline S4 & $3151.1 \pm 189.6 \mathrm{Aa}$ & $3037.8 \pm 378.9 \mathrm{Aa}$ & $3060.7 \pm 890.5 \mathrm{Aa}$ & $3194.5 \pm 256.3 \mathrm{Aa}$ & $2971.9 \pm 741.3 \mathrm{Aa}$ & NS \\
\hline S5 & $3405.5 \pm 311.3 \mathrm{Aa}$ & $3326.1 \pm 648.9 \mathrm{Aa}$ & $3163.8 \pm 453.8 \mathrm{Aa}$ & $3163.4 \pm 444.4 \mathrm{Aa}$ & $3433.6 \pm 508.8 \mathrm{Aa}$ & NS \\
\hline S6 & $3871.7 \pm 448.3 \mathrm{Aa}$ & $3793.5 \pm 284.4 \mathrm{Aa}$ & $3508.7 \pm 726.2 \mathrm{Aa}$ & $3823.1 \pm 583.6 \mathrm{Aa}$ & $3626.2 \pm 467.9 \mathrm{Aa}$ & NS \\
\hline \multicolumn{7}{|c|}{ 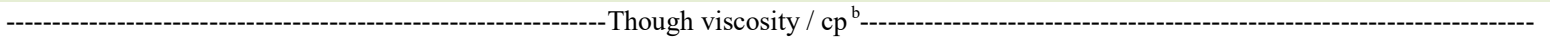 } \\
\hline S1 & $145.9 \pm 133.2 \mathrm{Bb}$ & $1778.5 \pm 1400.6$ Aa & $1734.3 \pm 942.2 \mathrm{Aa}$ & $1708.9 \pm 1430.0 \mathrm{Aa}$ & $730.2 \pm 728.2 \mathrm{Bb}$ & ** \\
\hline S2 & $1341.0 \pm 1063.5 \mathrm{Bb}$ & $2538.9 \pm 344.3 \mathrm{Aa}$ & $2325.2 \pm 772.8 \mathrm{Aa}$ & $1945.6 \pm 1103.3 \mathrm{Aa}$ & $2191.1 \pm 724.0 \mathrm{Aa}$ & NS \\
\hline S3 & $2592.1 \pm 463.3 \mathrm{Aa}$ & $2827.7 \pm 359.9 \mathrm{Aa}$ & $2506.5 \pm 408.7 \mathrm{Aa}$ & $2830.5 \pm 470.4 \mathrm{Aa}$ & $2453.7 \pm 278.7 \mathrm{Bb}$ & NS \\
\hline S4 & $2953.6 \pm 168.3 \mathrm{Aa}$ & $2797.2 \pm 334.2 \mathrm{Ab}$ & $3052.7 \pm 293.0 \mathrm{Aa}$ & $2887.3 \pm 257.7 \mathrm{Aa}$ & $2981.7 \pm 315.6 \mathrm{Aa}$ & $*$ \\
\hline S5 & $3111.9 \pm 189.0 \mathrm{Aa}$ & $2968.9 \pm 602.5 \mathrm{Aa}$ & $2763.0 \pm 590.6 \mathrm{Aa}$ & $2705.0 \pm 410.2 \mathrm{Bb}$ & $3190.9 \pm 490.4 \mathrm{Aa}$ & NS \\
\hline S6 & $3154.5 \pm 462.1 \mathrm{Aa}$ & $3104.2 \pm 422.7 \mathrm{Aa}$ & $2934.1 \pm 500.1 \mathrm{Aa}$ & $2877.7 \pm 494.0 \mathrm{Ab}$ & $3250.9 \pm 349.5 \mathrm{Aa}$ & NS \\
\hline \multicolumn{7}{|c|}{ 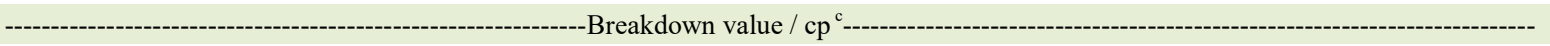 } \\
\hline S1 & $266.8 \pm 73.6 \mathrm{Bb}$ & $842.7 \pm 838.0 \mathrm{Aa}$ & $225.7 \pm 225.2 \mathrm{Bb}$ & $610.1 \pm 761.6 \mathrm{Aa}$ & $280.1 \pm 155.2 \mathrm{Ab}$ & NS \\
\hline S2 & $331.1 \pm 254.5 \mathrm{Aa}$ & $227.6 \pm 230.7 \mathrm{Aa}$ & $198.6 \pm 174.9$ Aa & $371.1 \pm 247.9 \mathrm{Aa}$ & $133.8 \pm 114.9 \mathrm{Bb}$ & NS \\
\hline S3 & $529.5 \pm 676.2 \mathrm{Aa}$ & $186.8 \pm 121.9 \mathrm{Ac}$ & $290.1 \pm 220.6 \mathrm{Ab}$ & $465.3 \pm 554.6 \mathrm{Aa}$ & $205.6 \pm 201.5 \mathrm{Ab}$ & * \\
\hline S4 & $197.1 \pm 124.6$ Аа & $236.0 \pm 197.8 \mathrm{Aa}$ & $263.5 \pm 134.3 \mathrm{Aa}$ & $307.6 \pm 166.1 \mathrm{Aa}$ & $156.7 \pm 98.4 \mathrm{Bb}$ & NS \\
\hline S5 & $293.6 \pm 186.8 \mathrm{Aa}$ & $357.2 \pm 356.9 \mathrm{Aa}$ & $400.8 \pm 262.7 \mathrm{Aa}$ & $458.4 \pm 320.7 \mathrm{Aa}$ & $242.7 \pm 168.0 \mathrm{Ab}$ & NS \\
\hline S6 & $717.2 \pm 438.3 \mathrm{Aa}$ & $691.0 \pm 645.9 \mathrm{Aa}$ & $624.7 \pm 624.4 \mathrm{Aa}$ & $978.8 \pm 588.6 \mathrm{Aa}$ & $376.5 \pm 348.8 \mathrm{Bb}$ & NS \\
\hline \multicolumn{7}{|c|}{ - } \\
\hline S1 & $255.7 \pm 206.3 \mathrm{Cc}$ & $2155.0 \pm 1685.4 \mathrm{Bb}$ & $2487.1 \pm 1488.4 \mathrm{Aa}$ & $2097.5 \pm 1770.0 \mathrm{Aa}$ & $1167.7 \pm 1326.2 \mathrm{Ab}$ & ** \\
\hline $\mathrm{S} 2$ & $1927.7 \pm 1621.8 \mathrm{Cc}$ & $3756.7 \pm 439.5 \mathrm{Aa}$ & $3244.1 \pm 1327.9 \mathrm{Bb}$ & $\begin{array}{c}2486.3 \pm 1549.7 \\
\mathrm{Ab}\end{array}$ & $\begin{array}{c}3466.0 \pm 1153.9 \\
\text { Aa }\end{array}$ & NS \\
\hline S3 & $3903.5 \pm 470.8 \mathrm{Aa}$ & $3950.9 \pm 327.8 \mathrm{Aa}$ & $3557.8 \pm 753.6 \mathrm{Aa}$ & $3748.6 \pm 655.9 \mathrm{Aa}$ & $3859.6 \pm 462.1 \mathrm{Aa}$ & NS \\
\hline S4 & $4003.4 \pm 666.8$ Aa & $4167.0 \pm 861.3 \mathrm{Aa}$ & $3881.1 \pm 698.3 \mathrm{Aa}$ & $3582.1 \pm 613.6 \mathrm{Bb}$ & $4452.3 \pm 594.5 \mathrm{Aa}$ & NS \\
\hline S5 & $3982.8 \pm 455.6$ Aa & $4032.1 \pm 752.0 \mathrm{Aa}$ & $3615.9 \pm 748.8 \mathrm{Aa}$ & $3619.3 \pm 711.6 \mathrm{Ab}$ & $4134.5 \pm 547.3 \mathrm{Aa}$ & NS \\
\hline S6 & $3897.8 \pm 1046.7 \mathrm{Aa}$ & $3622.1 \pm 705.1 \mathrm{Aa}$ & $3881.6 \pm 865.1 \mathrm{Aa}$ & $3292.6 \pm 738.0 \mathrm{Bb}$ & $4308.3 \pm 695.4 \mathrm{Aa}$ & NS \\
\hline \multicolumn{7}{|c|}{--1-- } \\
\hline S1 & $177.5 \pm 180.8 \mathrm{Cc}$ & $374.3 \pm 332.0 \mathrm{Bb}$ & $782.0 \pm 621.8 \mathrm{Aa}$ & $454.0 \pm 303.0 \mathrm{Aa}$ & $435.2 \pm 621.2 \mathrm{Aa}$ & $* *$ \\
\hline S2 & $587.8 \pm 600.4 \mathrm{Ac}$ & $1219.5 \pm 446.4 \mathrm{Aa}$ & $918.0 \pm 819.6 \mathrm{Ab}$ & $541.5 \pm 495.7 \mathrm{Bb}$ & $1275.3 \pm 646.6 \mathrm{Aa}$ & NS \\
\hline S3 & $1310.5 \pm 620.0 \mathrm{Aa}$ & $1123.1 \pm 583.6 \mathrm{Aa}$ & $1052.1 \pm 613.5 \mathrm{Aa}$ & $918.1 \pm 610.1 \mathrm{Ab}$ & $1405.8 \pm 499.1 \mathrm{Aa}$ & NS \\
\hline S4 & $1408.9 \pm 769.5 \mathrm{Aa}$ & $1365.6 \pm 692.0 \mathrm{Aa}$ & $828.4 \pm 682.0 \mathrm{Ab}$ & $694.7 \pm 668.0 \mathrm{Bb}$ & $1467.2 \pm 590.9 \mathrm{Aa}$ & NS \\
\hline S5 & $870.9 \pm 357.9 \mathrm{Aa}$ & $1063.2 \pm 882.4 \mathrm{Aa}$ & $852.9 \pm 600.4 \mathrm{Aa}$ & $914.3 \pm 600.6 \mathrm{Aa}$ & $943.6 \pm 697.3 \mathrm{Aa}$ & NS \\
\hline S6 & $743.3 \pm 774.0 \mathrm{Ab}$ & $517.8 \pm 360.8 \mathrm{Ac}$ & $1054.5 \pm 700.7 \mathrm{Aa}$ & $486.2 \pm 424.9 \mathrm{Bb}$ & $1057.5 \pm 740.5 \mathrm{Aa}$ & NS \\
\hline \multicolumn{7}{|c|}{ - } \\
\hline S1 & $89.58 \pm 0.94 \mathrm{Aa}$ & $80.93 \pm 9.18 \mathrm{Bb}$ & $75.20 \pm 12.44 \mathrm{Cc}$ & $77.32 \pm 12.03 \mathrm{Bb}$ & $86.47 \pm 6.41 \mathrm{Aa}$ & $*$ \\
\hline $\mathrm{S} 2$ & $81.39 \pm 8.51 \mathrm{Aa}$ & $72.51 \pm 1.20 \mathrm{Bb}$ & $74.58 \pm 5.26 \mathrm{Bb}$ & $77.35 \pm 7.93 \mathrm{Aa}$ & $74.96 \pm 5.51 \mathrm{Aa}$ & NS \\
\hline S3 & $73.05 \pm 1.53 \mathrm{Aa}$ & $72.06 \pm 0.72 \mathrm{Aa}$ & $71.35 \pm 6.53 \mathrm{Aa}$ & $71.20 \pm 4.95 \mathrm{Aa}$ & $73.10 \pm 2.06 \mathrm{Aa}$ & NS \\
\hline S4 & $71.14 \pm 1.56 \mathrm{Aa}$ & $71.33 \pm 0.87 \mathrm{Aa}$ & $71.91 \pm 1.69 \mathrm{Aa}$ & $71.17 \pm 1.62 \mathrm{Aa}$ & $71.74 \pm 1.16 \mathrm{Aa}$ & NS \\
\hline S5 & $69.46 \pm 1.72 \mathrm{Bb}$ & $70.28 \pm 1.14 \mathrm{Bb}$ & $71.46 \pm 0.99 \mathrm{Aa}$ & $69.72 \pm 1.70 \mathrm{Bb}$ & $71.07 \pm 0.98 \mathrm{Aa}$ & \\
\hline S6 & $68.96 \pm 2.46 \mathrm{Bb}$ & $68.93 \pm 1.57 \mathrm{Bb}$ & $70.93 \pm 1.68 \mathrm{Aa}$ & $68.23 \pm 1.95 \mathrm{Bb}$ & $70.98 \pm 1.21 \mathrm{Aa}$ & NS \\
\hline
\end{tabular}

Note: Different large and small letters in the same row indicate significant difference among varieties at 0.01 and 0.05 level, respectively. ${ }^{* *}$ and ${ }^{*}$ indicate significance in interaction at $1 \%$ and $5 \%$ level, respectively. NS means no significance in interaction. 
starch content and granule size was still unclear in potato tuber. The study showed that HV had smaller average starch granule size than MV and LV during S1-S6 (Table $3^{\mathrm{a}}$ ). We speculated that HV plant was more prosperous than MV and LV plant because of its strong photosynthetic and assimilates transport capacity, and the ease of the part of leucoplasts turning into small starch granule, which led to the increase of the number of small starch granules and the decrease of average starch granule size for HV.

Starch pasting temperature was different among the varieties with different starch content (TSAI et al., 1997; SASAKI et al., 2000; LIANG et al., 2009; SHI et al., 2011; KIM \& HUBER, 2010). This study revealed that HV showed higher pasting temperature than $\mathrm{MV}$ and LV before S3, and lower pasting temperature than MV and LV after S4 (Table $\left.4^{f}\right)$. We suggested that the higher pasting temperature of HV could be caused by the smaller average starch particle size before S3, which was consistent with the results of KAUR et al. (2007), and the lower pasting temperature of $\mathrm{HV}$ might be caused by the larger proportion of large starch particle after S4, which warrants further investigation.

\section{Significance of path analysis}

The path analysis should be a closed system as far as possible (LAVANYA et al., 2019; SHUBHA \& SINGH, 2018), and $\mathrm{R}^{2}$ should be above 0.9 as far as possible (REN et al., 2003). In this paper, $\mathrm{R}^{2}$ was between 0.7 and 0.9 (Table 5), which indicated that the influence factor estimation of starch gelatinization properties was not complete, and some factors still needed to be discussed (BURTON et al., 2002; BALL \& MORELL, 2003; TAKAHA et al., 1998; STEUP et al., 1983; STENSBALLE et al., 2008).

In this study we reported that when tuber development entered S4 stage, the activities of starch synthesis key enzymes begin to play a key role in the determination of gelatinization properties of $\mathrm{HV}$ (Table $5^{\mathrm{d}}$ ); whereas the gene expressions of starch synthesis key enzymes play the most important role in the determination of the gelatinization properties of MV and LV (Table $5^{\text {end }}$ ). Such a finding is significant as it suggests that in the actual production and the starch accumulation period, measures should be taken to enhance the activities of the starch synthesis key enzymes for $\mathrm{HV}$, and the gene expressions of starch synthesis key enzymes for MV and LV, in order to

Table 5 - Path analysis of forming factors and starch gelatinization properties in potato tubers with different starch content and period.

\begin{tabular}{|c|c|c|c|c|c|c|c|c|c|c|}
\hline \multirow[t]{2}{*}{ Factors } & \multirow{2}{*}{$\begin{array}{c}\text { Direct } \\
\text { coefficient }\end{array}$} & --------.- & direct pa & coefficie & ----------- & \multirow{2}{*}{$\begin{array}{c}\text { Direct } \\
\text { coefficient }\end{array}$} & \multicolumn{4}{|c|}{-----------Indirect path coefficient--------- } \\
\hline & & FF1 & FF2 & FF3 & FF4 & & FF1 & FF2 & FF3 & FF4 \\
\hline & \multicolumn{5}{|c|}{ 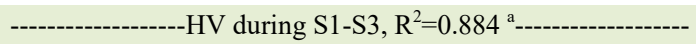 } & \multicolumn{5}{|c|}{ 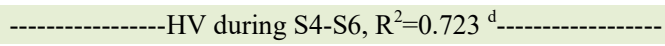 } \\
\hline FF1 & 0.751 & & -0.506 & 0.067 & 0.352 & 0.024 & & -0.015 & -0.310 & -0.005 \\
\hline FF2 & -0.757 & 0.483 & & -0.156 & 0.015 & -0.625 & 0.236 & & -0.037 & 0.066 \\
\hline FF3 & -0.337 & 0.248 & -0.129 & & -0.081 & -0.297 & 0.199 & -0.089 & & -0.031 \\
\hline \multirow[t]{2}{*}{ FF4 } & 0.285 & 0.051 & -0.065 & 0.079 & & -0.173 & 0.143 & 0.062 & 0.044 & \\
\hline & \multicolumn{5}{|c|}{----MV during S1-S3, R ${ }^{2}=0.835^{\mathrm{b}}$} & \multicolumn{5}{|c|}{ 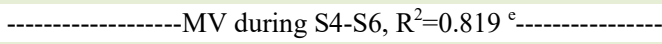 } \\
\hline FF1 & -0.465 & & 0.149 & 0.276 & 0.580 & -0.317 & & 0.529 & 0.0001 & -0.277 \\
\hline FF2 & -0.508 & 0.012 & & 0.016 & 0.055 & 0.238 & -0.097 & & 0.065 & -0.390 \\
\hline FF3 & 0.217 & -0.089 & -0.263 & & 0.257 & -0.120 & -0.069 & -0.097 & & -0.061 \\
\hline FF4 & -0.038 & 0.187 & 0.087 & 0.040 & & 0.065 & 0.068 & -0.022 & -0.017 & \\
\hline \multicolumn{6}{|c|}{ 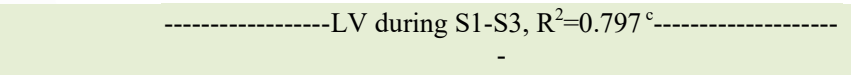 } & \multicolumn{5}{|c|}{ 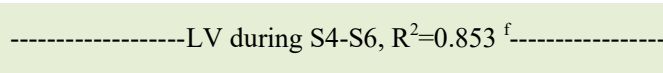 } \\
\hline FF1 & -0.032 & & -0.090 & -0.050 & -0.002 & 0.576 & & -0.452 & -0.090 & -0.094 \\
\hline FF2 & 0.368 & 0.061 & & -0.195 & -0.027 & -0.253 & -0.283 & & 0.162 & 0.210 \\
\hline FF3 & -0.276 & 0.205 & 0.313 & & -0.023 & 0.186 & -0.188 & -0.231 & & 0.135 \\
\hline FF4 & 0.052 & 0.124 & -0.051 & 0.001 & & -0.267 & 0.123 & 0.109 & -0.021 & \\
\hline
\end{tabular}

Note: Dependent variables consist of peak viscosity, trough viscosity, breakdown value, final viscosity, setback value and pasting temperature; Independent variables consist of FF1 (AGPase, SSII, SSIII, GBSSI, SBEI, SBEII relative gene expression), FF2 (AGPase, SSS, GBSS, SBE enzyme activity), FF3 (total starch content, amylose content, amylose/amylopectin ratio) and FF4 (median diameter, dispersion). The values in the table are the average of dependent variables. 
improve the starch quality of potato tuber. However, the underlying mechanisms remain to be elucidated.

\section{CONCLUSION}

This two-year field experiment provides new empirical knowledge about the starch synthesis and gelatinization properties of potato tubers with different starch content. First, phases do exist in starch synthesis of potato during the process of tuber development, and S3-S4 is the turning point. Second, efficient synthesis of amylopectin and its branches is largely attributable for the high level of starch accumulation in potato tubers after S4. Third, smaller average starch granule size accompanies by lower starch pasting temperature for HV after S4. Last, compared with MV and LV, the activities of starch synthesis key enzymes begin to play a key role in the determination of gelatinization properties of HV when tuber development entered S4 stage. Thus, the application of starch in potato varieties with three starch types was different in food and non-food processing, among them, HV starch was more suitable for processing bread and noodles, while LV starch was more suitable for processing cakes and biscuits.

\section{ACKNOWLEDGEMENTS}

This work was jointly supported by the Natural Science Foundation of Qinghai Province (2017-ZJ-960Q), the Opening Foundation of Key Laboratory of Biology and Genetic Improvement of Tuber and Root Crop, Ministry of Agriculture and Rural Affairs, P. R. China (NYBSL201704), the Major Science and Technology Project of Qinghai Province (2019-NK-A1), and the Agricultural Industry Technology System (CARS-9).

\section{DECLARATION OF CONFLICT OF INTEREST}

The authors declare no conflict of interest. The founding sponsors had no role in the design of the study; in the collection, analyses, or interpretation of data; in the writing of the manuscript, and in the decision to publish the results.

\section{AUTHORS' CONTRIBUTIONS}

All authors have made contributions to the present research. Wang Su was fully engaged in the paper writing and revision. Guangji Ye was offered great insights in theoretical part. Yun Zhou and Jian Wang played the role of supervisors. All authors approved of the final version.

\section{REFERENCES}

ALBRECHT, T. et al. Plastidic (Pho1-type) phosphorylase isoforms in potato (Solanum tuberosum L.) plants: Expression analysis and immunochemical characterization. Planta. v.213(n.4), p.602-613,
2001. Available from: <https://link.springer.com/article/10.1007/ s004250100525>. Accessed: Nov. 12, 2020. doi: 10.1007/ s004250100525.

BALL, S. G.; MORELL, M. K. From bacterial glycogen to starch: understanding the biogenesis of the plant starch granule. Annual Review of Plant Biology. v.54(n.1), p.207-233, 2003. Available from: <https://pubmed.ncbi.nlm.nih.gov/14502990/>. Accessed: Nov. 12, 2020. doi: 10.1146/annurev.arplant.54.031902.134927.

BAO, J. et al. Analysis of genotypic and environmental effects on rice starch. 1. Apparent amylase content, pasting viscosity, and gel texture. Journal of Agricultural and Food Chemistry. v.52(n.19), p.6010-6016, 2004. Available from: <https://pubmed.ncbi.nlm.nih. gov/15366856/>. Accessed: Nov. 12, 2020. doi: 10.1021/jf049234i.

BURTON, R.A., et al. Starch granule initiation and growth are altered in barley mutants that lack isoamylase activity. The Plant Journal. v.31(n.1), p.97-112, 2002. Available from: <https:// onlinelibrary.wiley.com/doi/10.1046/j.1365-313x.2002.01339.x>. Accessed: Nov. 12, 2020. doi: 10.1046/j.1365-313X.2002.01339.x.

BUSTOS, R., et al. Starch granule initiation is controlled by a heteromultimeric isoamylase in potato tubers. Proceedings of the National Academy of Sciences of the United States of America. v.101(n.7), p.2215-2220, 2004. Available from: <https://www. pnas.org/content/101/7/2215>. Accessed: Nov. 12, 2020. doi: $10.1073 /$ pnas.0305920101.

$\mathrm{CAO}, \mathrm{X}$., et al. Effects of late-stage nitrogen fertilizer application on the starch structure and cooking quality of rice. Journal of the Science of Food and Agriculture. v.98(n.6), p.2332-2340, 2018. Available from: <https://onlinelibrary.wiley.com/doi/pdf/10.1002/ jsfa. 8723>. Accessed: Nov. 12, 2020. doi: 10.1002/jsfa.8723.

CHEN, W. T., et al. Effects of charge-carrying amino acids on the gelatinization and retrogradation properties of potato starch. Food Chemistry. v.167, p.180-184, 2015. Available from: $<$ https://www. sciencedirect.com/science/article/pii/S030881461400987X >. Accessed: Nov. 12, 2020. doi: 10.1016/j.foodchem.2014.06.089.

CHENG, F. M., et al. The dynamic change of starch synthesis enzymes during the grain filling stage and effects of temperature upon it. Acta Agronomica Sinica. v.27(n.2), p.201-206, 2001. Available from: <https://www.ixueshu.com/document/ f6e4da5e66ab94b2318947a18e7 f9386.html>. Accessed: Nov. 12, 2020. doi: 10.3321/j.issn:0496-3490.2001.02.011. (In Chinese with English abstract).

CHINA NATIONAL BUREAU OF STATISTICS, 2011-2020. China Statistical Yearbook. Beijing, China Statistics Press, 20112020. (In Chinese).

COVENTRY, D. R., et al. Effect of tillage and nutrient management on wheat productivity and quality in Haryana, India. Field Crops Research. v.123(n3), p.234-240, 2011. Available from: <https:// www.sciencedirect.com/science/article/pii/S0378429011001791>. Accessed: Nov. 12, 2020. doi: 10.1016/j.fcr.2011.05.016.

DAVIS, J. P., et al. Synthesis of novel starches in planta: Opportunities and challenges. Starch-Starke. v.55(n.3-4), p.107-120, 2003. Available from: <https://onlinelibrary.wiley.com/doi/abs/10.1002/star.200390036>. Accessed: Nov. 12, 2020. doi: 10.1002/star. 200390036.

DELATTE, T., et al. Arabidopsis mutants Atisa1 and Atisa2 have identical phenotypes and lack the same multimeric isoamylase, 
which influences the branch point distribution of amylopectin during starch synthesis. The Plant Journal. v.41(n.6), p.815830, 2005. Available from: <https://onlinelibrary.wiley.com/doi/ pdf/10.1111/j.1365-313X.2005.02348.x>. Accessed: Nov. 12, 2020. doi: 10.1111/j.1365-313X.2005.02348.x.

DU, H. H., et al. Effects of RNAi silencing of SSIII gene on phosphorus content and characteristics of starch in potato tubers. Journal of Integrative Agriculture. v.11(n.12), p.1985-1992, 2012. Available from: <https://www.sciencedirect.com/science/ article/pii/S209 5311912604559>. Accessed: Nov. 12, 2020. doi: $10.1016 /$ S2095-3119(12)60455-9.

DUWENIG, E., et al. Antisense inhibition of cytosolic phosphorylase in potato plants (Solanum tuberosum L.) affects tuber sprouting and flower formation with only little impact on carbohydrate metabolism. The Plant Journal. v.12(n.2), p.323333 , 1997. Available from: <https://onlinelibrary.wiley.com/ doi/10.1046/j.1365-313X.1997.12020323.x>. Accessed: Nov. 12, 2020. doi: 10.1046/j.1365-313X.1997.12020323.x.

EDWARDS, A., et al. A combined reduction in activity of starch synthases II and III of potato has novel effects on the starch of tubers. The Plant Journal. v.17(n.3), p.251-261, 1999. Available from: <https://onlinelibrary.wiley.com/doi/10.1046/ j.1365-313X.1999.00371.x>. Accessed: Nov. 12, 2020. doi: 10.1046/j.1365-313X.1999.00371.x.

EMES, M. J.; NEUHAUS, H. E. Metabolism and transport in non-photosynthetic plastids. Journal of Experimental Botany v.48(n.12), p.1995-2005, 1997. Available from: $<$ https://academic. oup.com/jxb/article/48/12/1995/681639>. Accessed: Nov. 12, 2020. doi: $10.1093 / \mathrm{jxb} / 48.12 .1995$.

FENG, P. B., et al. Effect of high temperature on potato starch content, amylase activity and yield. Southwest China Journal of Agricultural Sciences. v.32(n.6), p.1253-1258, 2019. Available from: <http://en.cnki.com.cn/Article_en/CJFDTotalXNYX201906008.htm>. Accessed: Nov. 12, 2020. doi: 10.16213/j. cnki.scjas.2019.6.008. (In Chinese with English abstract).

FERREIRA, S. J., et al. Simultaneous silencing of isoamylases ISA1, ISA 2 and ISA 3 by multi-target RNAi in potato tubers leads to decreased starch content and an early sprouting phenotype. PLoS One. v.12(n.7), e0181444, 2017. Available from: <https:// pubmed.ncbi.nlm. nih.gov/28708852/>. Accessed: Nov. 12, 2020. doi: 10.1371/journal.pone.0181444

FULTON, D. C., et al. Role of granule-bound starch synthase in determination of amylopectin structure and starch granule morphology in potato. Journal of Biological Chemistry. v. 277(n.13), p.10834-10841, 2002. Available from: <https://pubmed. ncbi.nlm.nih.gov/1180 1600/>. Accessed: Nov. 12, 2020. doi: 10.1074/jbc.M111579200.

GALKOWSKA, D., et al. Influence of cassia gum on rheological and textural properties of native potato and corn starch. Starch/ Starke. v.66, p.1060-1070, 2014. Available from: <https:// onlinelibrary.wiley.com/doi/10.1002/star.201400078>. Accessed: Nov. 12, 2020. doi: 10.1002/star.201400078.

GEIGENBERGER, P., et al. Redox regulation of carbon storage and partitioning in response to light and sugars. Journal of Experimental Botany. v.56(n.416), p.1469-1479, 2005. Available from: <https://pubmed.ncbi.nlm.nih.gov/15863446/>. Accessed: Nov. 12, 2020. doi: 10.1093/jxb/eri178.
GUO, S. M., et al. Study on physiological basis of high starch potatoes - the relationship of tuber starch content with nitrogen, phosphorous and potassium metabolism. Chinese Potato Journal. v.7(n.2), p.6570, 1993. Available from: <https://www.ixueshu.com/document/ a81a204ccd14fe1dbdb36176839f4c6f318947a18e7f9386.html> . Accessed: Nov. 12, 2020. (In Chinese with English abstract)

HOVENKAMP-HERMELINK, J. H. M., et al. Isolation of an amylose-free starch mutant of the potato (Solanum tuberosum L.). Theoretical and Applied Genetics. v.75(n.1), p.217-221, 1987. Available from: <https://link.springer.com/article/10.1007/ BF00249167>. Accessed: Nov. 12, 2020. doi: 10.1007/ BF00249167.

HUANG, X. F., et al. Expression of an amylosucrase gene in potato results in larger starch granules with novel properties. Planta. v.240, (n.2), p.409-421, 2014. Available from: <https:// link.springer.com/article/10.1007/s00425-014-2095-1>. Accessed: Nov. 12, 2020. doi: 10.1007/s00425-014-2095-1.

JOBLING, S. A., et al. A minor form of starch branching enzyme in potato (Solanum tuberosum L.) tubers has a major effect on starch structure: Cloning and characterization of multiple forms of SBE A. The Plant Journal. v.18, (n.2), p.163-171, 1999. Available from: <https://onlinelibrary.wiley.com/doi/full/10.1046/ j.1365-313X.1999.00441.x>. Accessed: Nov. 12, 2020. doi: 10.1046/j.1365-313X.1999.00441.x.

KAUR, A., et al. Physicochemical, thermal and pasting properties of starches separated from different potato cultivars grown at different locations. Food Chemistry. v.101, (n.2), p.643-651, 2007. Available from: <https://www.sciencedirect.com/science/ article/pii/S0308814606001348>. Accessed: Nov. 12, 2020. doi: 10.1016/j.foodchem.2006.01.054.

KIM, H. S.; HUBER, K. C. Impact of A/B-type granule ratio on reactivity, swelling, gelatinization, and pasting properties of modified wheat starch. Part I: Hydroxypropylation. Carbohydrate Polymers. v.80(n.1), p.94-104, 2010. Available from: <https://www.science direct.com/science/article/pii/ S0144861709006286>. Accessed: Nov. 12, 2020. doi: 10.1016/j. carbpol.2009.10.070.

LAVANYA, K. S., et al. Correlation and path analysis for yield and yield-related traits of potato (Solanum tuberosum L.) in Karnataka. National Academy Science Letters. v.43, p.137-140, 2019. Available from: <https://link.springer.com/article/10.1007/ s40009-019-00831-z>. Accessed: Nov. 12, 2020. doi: 10.1007/ s40009-019-00831-z.

LI, T. G., et al. Effect of Q-enzyme on the chalkiness formation of rice grain. Acta Agronomica Sinica. v.23, (n.3), p.338-344, 1997. Available from: $<$ https://en.cnki.com.cn/Article_en/CJFDTOTALXBZW199703013.htm>. Accessed: Nov. 12, 2020. (In Chinese with English abstract).

LIANG, L. S., et al. Relationship between starch pasting, amylase content and starch granule size in different Chinese chestnut variety groups. Scientia Agricultura Sinica. v.42, (n.1), p.251-260, 2009. Available from: <http://en.cnki.com.cn/Article_en/CJFDTOTALZNYK200901034.htm>. Accessed: Nov. 12, 2020. doi: 10.3864/j. issn.0578-1752.2009.01.032. (In Chinese with English abstract).

LIU, M. Y., et al. Studies on the physiological basis of high starch potatoes - the relationship between tissue structure and starch accumulation. Chinese Potato Journal. v.8, (n.3), p.129- 
133, 1994. Available from: <http://en.cnki.com.cn/Article_en/ CJFDTOTAL-MLSZ199403000.htm>. Accessed: Nov. 12, 2020. (In Chinese with English abstract).

LLOYD, R., et al. The influence of alterations in ADP-glucose pyrophosphorylase activities onstarch structure and composition in potato tubers. Planta. v.209, (n.2), p.230-238, 1999. Available from: <https://link.springer.com/article/10.1007/s004250050627>. Accessed: Nov. 12, 2020. doi: 10.1007/s004250050627.

LOU, S. B., et al. Relationship between tuber size and potato starch granule distribution. Chinese Potato Journal. v.24, (n.4), p.199202, 2010. Available from: <http://en.cnki.com.cn/Article en/ CJFDTOTAL-MLSZ201004005.htm>. Accessed: Nov. 12, 2020 (In Chinese with English abstract).

MA, G. S., et al. The effect of element boron on potato starch synthesis and accumulation. Journal of Nuclear Agricultural Sciences. v.27, (n.3), p.384-390, 2013. Available from: <http:// en.cnki.com.cn/Article en/CJFDTOTAL-HNXB201303022. htm>. Accessed: Nov. 12, 2020. (In Chinese with English abstract).

MARSHALL, J., et al. Identification of the major starch synthase in the soluble fraction of potato tubers. Plant Cell. v.8, (n.7), p.1121-1135, 1996. Available from: <https://pubmed.ncbi.nlm. nih.gov/8768372/>. Accessed: Nov. 12, 2020. doi: 10.1105/ tpc.8.7.1121

MEN, F. Y., et al. Study on high starch physiological basis of potato - the relationship between tuber starch content and some physiological characteristic of plant. Chinese Potato Journal v.7, (n.1), p.1-6, 1993a. Available from: <http://en.cnki.com.cn/ Article en/CJFDTOTAL-MLSZ199301000.htm>. Accessed: Nov. 12, 2020. (In Chinese with English abstract).

MEN, F. Y., et al. Studies on physiological basis of high starch potatoes - the relationship between tuber starch content and sugar metabolism. Chinese Potato Journal. v.7, (n.3), p.129133, 1993b. Available from: <http://en.cnki.com.cn/Article_en/ CJFDTOTAL-MLSZ199303000.htm>. Accessed: Nov. 12, 2020. (In Chinese with English abstract).

MEN, F. Y., et al. Studies on physiological basis of high starch potatoes - the relationship between tuber starch content and characters of plant. Chinese Potato Journal. v.7, (n.3), p.134138, 1993c. Available from: <http://en.cnki.com.cn/Article en/ CJFDTOTAL-MLSZ199303001.htm>. Accessed: Nov. 12, 2020. (In Chinese with English abstract).

MEN, F. Y., et al. Study on physiological basis of high starch potatoes - the relationship between starch content and substance transportation in mother potato tubers. Chinese Potato Journal. v.8, (n.1), p.1-5, 1994. Available from: <http://en.cnki.com.cn/ Article_en/CJFDTOTAL-MLSZ401.000.htm>. Accessed: Nov. 12, 2020. (In Chinese with English abstract).

MENG, M. L., et al. Studies on the physiological basis of the high starch content in the potato tuber - relationship between the tissue structure of leaf and the starch accumulation. Chinese Potato Journal. v.13, (n.3), p.136-140, 1999. Available from: <http:// qikan.cqvip.com/Qikan/Article/Detail?id=3703987>. Accessed: Nov. 12, 2020. (In Chinese with English abstract).

MÜLLER-RÖBER, B., et al. Inhibition of the ADP-glucose pyrophosphorylase in transgenic potatoes leads to sugar-storing tubers and influences tuber formation and expression of tuber storage protein genes. ЕМBO Journal. v.11(n.4), p.12291238, 1992. Available from: <https://www.embopress.org/doi/ abs/10.1002/j.1460-2075.1992.tb05167.x>. Accessed: Nov. 12, 2020. doi: $10.1002 / j .1460-2075.1992 . t b 05167 . x$.

NAKAMURA, Y., et al. Carbohydrate metabolism in the developing endosperm of rice grains. Plant and Cell Physiology. v.30, p.833-839, 1989. Available from: <https://academic.oup. com/pcp/article/30/6/833/1865953>. Accessed: Nov. 12, 2020. doi: 10.1093/oxfordjournals. pcp.a077813.

NIELSEN, T. H., et al. Intermediary glucan structures formed during starch granule biosynthesis are enriched in short side chains, a dynamic pulse labeling approach. Journal of Biological Chemistry. v.277(2n.3), p.20249-20255, 2002. Available from: <https://www. sciencedirect.com/science/article/pii/S0021925820848637>. Accessed: Nov. 12, 2020. doi: 10.1074/jbc.M201866200

PFAFFL, M. W. A new mathematical model for relative quantification in real-time RT-PCR. Nucleic Acids Research. v.29, (n.9), e45, 2001. Available from: <https://pubmed.ncbi. nlm.nih.gov/11328886/>. Accessed: Nov. 12, 2020. doi: 10.1093/ nar/29.9.e45.

QIU, C., et al. Effect of acid hydrolysis combined with moist heat treatmenton physicochemical properties of potato starch. Science and Technology of Cereals, Oils and Foods. v.23(n.2), p.17-21, 2015. Available from: <https://wenku.baidu.com/ view/97295795ba 4cf7ec4afe04a1b0717fd5360cb23d $>$. Accessed: Nov. 12, 2020. doi: 10.16210/j.cnki.1007- 7561.2015.02.013. (In Chinese with English abstract).

RAL, J. P., et al. Circadian clock regulation of starch metabolism establishes GBSSI as a major contributor to amylopectin synthesis in Chlamydomonas reinhardtii. Plant Physiology. v.142, (n.1), p.305-317, 2006. Available from: <https://academic.oup.com/ plphys/article/142/1/305/6106405>. Accessed: Nov. 12, 2020. doi: 10.1104/pp.106.081885.

REN, H. S., et al. The implemented method of SAS in path analysis. Computer and Agriculture. (v.4), p.17-19, 2003. Available from: $<$ https://www.ixueshu.com/document/ 3fb3a010272b8320.html>. Accessed: Nov. 12, 2020. (In Chinese with English abstract)

SAFFORD, R., et al. Consequences of antisense RNA inhibition of starch branching enzyme activity on properties of potato starch. Carbohydrate Polymers. v.35, (n.3-4), p.155-168, 1998. Available from: $<$ https://www.ingentaconnect.com/content/el/014 48617/1998/00000035/00000003/art00004>. Accessed: Nov. 12, 2020. doi: $10.1016 / \mathrm{S} 0144-8617(97) 00249-\mathrm{X}$.

SASAKI, T., et al. Effect of amylose content on gelatinization, retrogradation, and pasting properties of starches from waxy and nonwaxy wheat and their F1 seeds. Cereal Chemistry. v.77, (n.1), p.58-63, 2000. Available from: <http://europepmc.org/article/ AGR/IND22059572>. Accessed: Nov. 12, 2020. doi: 10.1094/ CCHEM.2000.77.1.58.

SCHWALL, G. P., et al. Production of very-high-amylose potato starch by inhibition of SBE A and B. Nature Biotechnology. v.18(n.5), p.551-554, 2000. Available from: <https://www.nature. com/articles/nbt0500_551>. Accessed: Nov. 12, 2020. doi: $10.1038 / 75427$

SHAFI, A., et al. Transgenic potato plants overexpressing SOD and APX exhibit enhanced lignification and starch biosynthesis 
with improved salt stress tolerance. Plant Molecular Biology Reporter. v.35, (n.5), p.504-518, 2017. Available from: <https:// link.springer.com/article/10.1007/s11105-017-1041-3>. Accessed: Nov. 12, 2020. doi: 10.1007/s11105-017- 1041-3.

SHI, C. Y., et al. Starch granule size distribution in storage roots of different types of sweetpotato cultivars. Scientia Agricultura Sinica. v.44, (n.21), p.4537-4543, 2011. Available from: <https:// en.cnki.com.cn/Article en/CJFDTOTAL-ZNYK201121029. htm>. Accessed: Nov. 12, 2020. doi: 10.3864/j.issn.05781752.2011.21.023. (In Chinese with English abstract).

SHI, L. J., et al. Effects of water deficit at flowering stage on yield and quality of fresh waxy maize. Acta Agronomica Sinica. v.44, (n.8), p.1205-1211，2018. Available from: <https://www. zhangqiaokeyan.com/academic-journal-cn_acta-agronomica-sinica thesis/0201270641343.html>. Accessed: Nov. 12, 2020. doi: 10.3724/ SP.J.1006.2018.01205. (In Chinese with English abstract).

SHIMADA, T., et al. Increase of amylose content of sweet potato starch by RNA interference of the starch branching enzyme II gene (IbSBEII). Plant Biotechnology. v.23, p.8590, 2006. Available from: <https://www.jstage.jst.go.jp/article/ plantbiotechnology/23/1/23 1 85/ article >. Accessed: Nov. 12, 2020. doi: $10.5511 /$ plantbiotechnology.23.85.

SHUBHA, K.; SINGH, D. Selection of yield-associated morphological and biochemical traits using correlation and path coefficient analysis in potato (Solanum tuberosum L.) in the foothills of North-Western Himalayas. Potato Research. v.61, p.273-281, 2018. Available from: <https://link.springer.com/ article/10.1007/s11540-018-9376-1>. Accessed: Nov. 12, 2020. doi: $10.1007 / \mathrm{s} 11540-018-9376-1$.

STARK, D. M., et al. Regulation of the amount of starch in plant tissues by ADP glucose pyrophosphorylase. Science. v.258, (n.5080), p.287-292, 1992. Available from: <https://science. sciencemag.org/content/258/5080/287>. Accessed: Nov. 12, 2020. doi: $10.1126 /$ science. 258.5080 .287

STENSBALLE, A., et al. The amyloplast proteome of potato tuber FEBS Journal. v.275, (n.8), p.1723-1741, 2008. Available from: $<$ https://pubmed.ncbi.nlm.nih.gov/18331355/>. Accessed: Nov. 12, 2020. doi: 10.1111/j.1742-4658.2008.06332.x.

STEUP, M., et al. In-vitro degradation of starch granules isolated from spinach chloroplasts. Planta. v.158, (n.5), p.428-436, 1983. Available from: <http://europepmc.org/article/med/ 24264852>. Accessed: Nov. 12, 2020. doi: 10.1007/BF00397736.

SU, W.; WANG, J. Potato and food security in China. American Journal of Potato Research. v.96, p.100-101, 2019. Available from: $<$ https://link.springer.com/article/10.1007/ s12230-018-09709-0>. Accessed: Nov. 12, 2020. doi: 10.1007/s12230-018-09709-0.
TAKAHA, T., et al. Normal starch content and composition in tubers of antisense potato plants lacking D- enzyme (4- $\alpha$-glucanotransferase). Planta. v.205, (n.3), p.445-451, 1998. Available from: <https://link.springer.com/article/10.1007/ s004250050342>. Accessed: Nov. 12, 2020. doi: 10.1007/ s004250050342.

TANG, H. L., et al. Relation between key enzymes of starch synthesis and tuber starch accumulation. Chinese Agricultural Science Bulletin. v.31, (n.27), p.88-93, 2015. Available from: <http:// en.cnki.com.cn/Article en/CJFDTOTAL-ZNTB201527017.htm>. Accessed: Nov. 12, 2020. (In Chinese with English abstract).

TIESSEN, A., et al. Starch synthesis in potato tubers is regulated by post-translational redox modification of ADP-Glucose pyrophosphorylase: A novel regulatory mechanism linking starch synthesis to the sucrose supply. Plant Cell. v.14, (n.9), p.2191-2213, 2002. Available from: <https://pubmed.ncbi.nlm. nih.gov/12215515/>. Accessed: Nov. 12, 2020. doi: 10.1105/ tpc. 003640 .

TSAI, M. L., et al. Effects of granular structures on the pasting behaviors of starches 1. Cereal Chemistry. v.74, (n.6), p.750757, 1997. Available from: <http://europepmc.org/article/ AGR/IND21238183>. Accessed: Nov. 12, 2020. doi: 10.1094/ cchem.1997.74.6.750.

WU, J. R., et al. Effects of black plastic film mulching on starch accumulation and key enzyme activities of potato tubers in dryland. Journal of Nuclear Agricultural Sciences. v.33, (n.12), p.24822491, 2019. Available from: <http://en.cnki.com.cn/Article en/ CJFDTotal-HNXB201912018.htm>. Accessed: Nov. 12, 2020. (In Chinese with English abstract).

YANG, $\mathrm{H}$., et al. Effects of nourishment on the key enzymes of starch synthesis in the process of tuber formation in autumn Solanum tuberosum L. Journal of Sichuan Agricultural University. v.31(n.1), p.9-14, 2013. Available from: <http:// en.cnki.com.cn/Article en/CJFD TOTAL-SCND201301003. htm>. Accessed: Nov. 12, 2020. doi: 10.3969/j.issn.1000-2650. 2013.01.002. (In Chinese with English abstract).

ZHANG, K. L., et al. Effect of ultrasonic treatment on structure and physicochemical properties of potato starch. Food Science. v.39, (n.5), p.128-134, 2018. Available from: <http://www.spkx. net.cn/CN/abstract/abstract43940.shtml>. Accessed: Nov. 12, 2020. doi: 10.7506/spkx1002-6630-201805020. (In Chinese with English abstract).

ZHOU, Q., et al. Waterlogging and simulated acid rain after anthesis deteriorate starch quality in wheat grain. Plant Growth Regulation. v.85, (n.2), p.257-265, 2018. Available from: $<$ https:// link.springer.com/article/10.1007/s10725-018-0390-8>. Accessed: Nov. 12, 2020. doi: 10.1007/s10725-018-0390-8. 